\title{
PARTiCipation OF INHABITANTS OF MUNICIPALITIES IN MEETINGS OF MUNICIPAL COUNCILS AND THEIR MODIFICATION IN THE Rules of Procedure of LocAL COUNCILS OF CITY DISTRICTS OF KOŠICE 1
}

\begin{abstract}
This paper deals with the possibility of the municipality's inhabitants to actively participate in the self-government of the municipality through participation in the meetings of the Municipal Council. This right arises to the inhabitants from the current legislation. Municipal Councils have the possibility within their Rules of Procedure to regulate the active participation of its residents and other persons who have the right to participate in the administration of public matters in the municipal self-government.
\end{abstract}

KEYWORDS: inhabitans, self- government, Rules of Procedure, participation, direct democracy

\section{INTRODUCTION}

Municipal self-government is accepted as a basic unit of territorial selfgovernment, which reflects the need for a territory that is defined, and through self-determination can react to the requirements of the municipality promptly and flexibly. The very concept of self-government in its conceptual and content definition counts on the implementation by itself, meaning by all concerned, or at least by the majority of managed entities (Krunková 2014). The Constitution 
of the Slovak Republic (hereinafter referred to as the "Constitution of the SR") determines the municipality as the foundation of territorial self-government for several reasons. This constitutional definition emphasizes the direct and close relationship of the municipality with its inhabitants, who represent a source of power in local conditions, and from which they divert their position as municipal authorities. Scientific literature mention opinions that the importance of the municipal establishment and its democratic functioning is sometimes more important than the functioning and organization of public authorities at higher levels of government (Palúš 2017).

The aim of the paper is to point out the possibilities of the city district inhabitants to actively participate in decision-making on important issues of the functioning and development of the city district, which should be adjusted, in the Rules of Procedure through the analysis of the current legislation, using literature and research of the Rules of the Procedure of individual city districts in Košice. Our ambition is also to emphasize the importance of public participation of inhabitants in the meetings of municipal (city, local) councils and of the overall involvement in governance.

\section{THEORETICAL BACKGROUND}

One of the basic features of the municipality is the personal foundation of the municipality, which consists of its inhabitants. The municipality, as a public corporation, is a territorial community associating residents with the permanent residence on its territory. It is the inhabitants who are the source of the municipal self-government power. As Alman (2017) states, the implementation of municipal self-government is directly related to the inhabitants of the municipality. In this context, the inhabitants of the municipality have a primacy, as they can be understood as a source of power, the executor of power and the addressee of self-government.

The Act on Municipal Establishment in defining of the personal basis is based on the concept that the municipality represents a certain territorial community of its permanent residents. It follows from the above that the Act on Municipal Establishment exceeds the Citizenship principle and the Personal nature of the municipality. Pursuant to $\$ 3$ par.2 to 4 of Act 
no. 369/1990 Coll. on Municipal Establishment, as amended (hereinafter referred to as the "Municipalities Act"), binds the right and duty to participate fully in the self-government of municipality to the condition of permanent residence of the person in the territory - the municipality citizen, regardless of his nationality (Tekeli 2016).

In addition to the residents of the municipality who have a permanent residence in the municipality, the person who has in its territory real estate, or is registered for temporary residence in the municipality may also participate. Furthermore, person who pays the local tax, local fee, or he was granted honorary citizenship of the village has the right to participate too. However, all of the above categories of individuals with the right to participate cannot vote or be elected to the municipal self-government bodies, nor can they vote in the local referendum (Jesenko 2017).

Municipal self-government is in the Slovak Republic performed by the inhabitants of the municipality either directly (local referendum and assembly of the inhabitants of the municipality) or through elected representatives (Municipal Council and mayor). However, at the municipal level, there are other forms of direct democracy through which the inhabitants of the municipality can participate in governance, and to which expert and scientific writings pay less attention. One of such forms of direct democracy is the active participation of the inhabitants of the municipality in the meetings of the Municipal Council.

The connection of direct democracy with the municipality selfgovernance as one of the ways of public power realizing in a democratic, legal state and territorial self-government, in our case municipal self-government, is undeniable. It is also understandable that the use of direct democracy is more efficient, less time-consuming and cheaper in a smaller area. Direct democracy at the municipality level must be within such a framework that it is also usable in real life.

Given the international documents dealing with this issue and in comparison, of the European countries, we consider direct democracy at community level:

- as the direct possibility of administration in the municipality (provided by Legal Order), meaning without representation, or mediation, 
- its implementation takes the form of direct democracy, ${ }^{2}$

- with regard to participation in such administration, there is a limit in connection with the age of the person concerned. The range of entities authorized to initiate, and, on the other hand, be a direct subject in the process of the administration must be clearly established without any doubt,

- for its own direct democracy realization, a provided mechanism must ensure equal opportunities for all eligible persons to participate, and all legal conditions have to be fulfilled. The representative bodies have the task of promoting the direct administration as an enriching and complementary possibility of the state power manifestation,

- the results obtained by the direct administration are equivalent to decisions taken by the municipal authorities and have the same ability to produce the same legal effects,

- no authority of the state or the representative bodies of the municipality may interfere with the results arising from the realization of direct democracy (Palúš - Jesenko - Krunková 2010).

One of the reasons for the use of individual forms of direct democracy is expanding of the possibilities for political groups that are not established and individuals to additionally participate in decision on public affairs and articulate their demands and ideas on this occasion. By using the institutes of direct democracy, unconventional ways of promoting new ideas or solving issues blocked due to the impossibility to compromise on the basis of representative democracy may also be accepted easier (Pavlíček et al. 2014).

Forms of direct democracy are an important tool for solving the problems associated with conflict situations and differences of opinion between representative bodies and diverse groups of society. The use of direct democracy also creates space for self-realization of the citizen. Direct decision-making alleviates the natural resistance against the representative bodies of the citizens concerned. Forms of direct democracy also act as a tool of action towards the excessive influence of political parties and the unsatisfactory behaviour of representative bodies. The use of direct democracy forms also provides the opportunity to express themselves to 
political and social groups of the population who are not represented in the representative body and usually do not participate in political life - partly or at all (Krunková 2016).

The Act on Municipalities in $\$ 11$ par.1 defines a municipality representative body as representative group composed of members who are elected directly by the inhabitants. The statutory definition of the municipality council activity is based directly from its constitutional conception, which is within the municipality considered as source of public power. The content of the Municipal Council competence is mainly related to the independent activity of the municipality ( $\$ 4$ par. 3 ). Subsequently, $\$ 11$ par.4 stipulates that the Municipal Council decides on basic life issues of the municipality and, above all, it is reserved for it to decide on matters which are demonstrably contained in provision of the Municipalities Act (Palúš et al. 2018).

The Municipal Council, as a collective body of the municipality, works in the form of meetings, which are understood as the time period within which it implements its competencies (see more: Sitek, 2018, 127-143). There are certain rules for the preparation and running of its meetings (time, personnel, organizational, procedural and local), which each council can specify in its own Rules of Procedure (Palúš - Jesenko - Krunková 2010). The Municipal Council, according to $\$ 12$ par. 11 , has the obligation to amend the detailed rules of its negotiations by the Rules of Procedure.

This municipality body should and must carry out its activities in connection with citizens and under their constant control - the Principle of the public (Sotolár 2011). According to $\$ 12$ par. 8 of the Act on Municipal Establishment of Municipal Councils, meetings are fundamentally public ${ }^{3}$. The deliberations of the Municipal Council cannot be declared non-public if the subject of the discussion is following:

using public funds for salaries, remuneration and other formalities connected with the performance of the municipal bodies' functions, members of municipal bodies, employees of the municipality or persons performing activities for the municipality who are paid for their performance,

Dealing with the property of the municipality, in particular transferring the ownership of the municipality's property, the acquiring of the property or passing the property of the municipality to other persons (Section 12 par. 8). 
By participating in the administration of municipality's public affairs we can also understand the participation of its inhabitants in the meetings of the Municipal Council. This right arises for the inhabitants of the municipality and other persons from the Act on Municipal Establishment. The Act on Municipalities in $\$ 3$ par. 2, sec. c) stipulates in the second part of the law the right of the inhabitants to participate in the meetings of the Municipal Council. The issues of the negotiations of the Municipal Council are very important, as the Municipal Council decides not only on the basic issues of the life of the municipality, but also on the concepts of development of individual areas. In order to ensure that the inhabitants of the municipality are informed about the decision-making activities of the Municipal Council, as well as their participation in its meetings, are in the Act on Municipal Establishment specified at least the basic principles. However, following the regulation of the second sentence of $\$ 12$ par. 9 we can state that a resident of the municipality has the right to participate in the meetings of the Municipal Council, but this does not mean that he / she is automatically entitled to speak and express his / her opinion.

The current legislation of the municipal establishment strictly distinguishes the possibility and the obligation to give a word. According to the first sentence of $\$ 12$ par. 9, word has to be given to a member of the National Council of the Slovak Republic, a member of the European Parliament, a government representative or a representative of another state body. The Member of the Municipal Council must also be given the floor if he requests to speak in connection with the agenda item. The Chairman may give the floor to any resident of the municipality as part of the discussion of individual items on the agenda. The possibility of giving the floor to a municipality resident is linked to two facts: discussing individual items on the agenda and permanent residence in the municipality (Sotolár 2011).

In this context, it is necessary to identify the ability to give the floor to the inhabitant and opportunity of the inhabitant to express their opinion ${ }^{4}$ in the municipality meeting. The expression of opinion is tied to the agenda discussed - Comments and inquiries of the inhabitants of the municipality, if such item is part of the Municipal Council's meeting. In practice, this means that, outside the point of the Municipal Council discussed, chairman may 
or may not give the citizen the floor. In the case of a separate agenda item - "Comments and questions from the inhabitants of the municipality", or "The Public word", is the chairman obliged to allow the inhabitants of the municipality to express their opinion. This item of the Municipal Council is intended to streamline the negotiations of the Municipal Council and to lead to the rational performance of public authority (Sotolár 2011).

\section{Participation of inhabitants at meetings OF THE MUNICIPAL COUNCIL SHOWED ON THE EXAMPLE OF THE KOŠICE CITY DISTRICTS}

Following part of the paper deals with the inhabitants' possibilities to contribute in the self-government of the Košice city districts and their modifications in the individual Rules of the Councils. As mentioned above, municipal governments, in this case the city districts of Košice, have the possibility to regulate the participation of the inhabitants of the municipality in the meetings of the Local Councils in various ways. One way is to allocate a separate item within the agenda of the Local Council, in which there is room for expressing the views, demands and problems of the inhabitants. However, city districts may also provide, in the Rules of Procedure, the opportunity to speak to the resident of the city council throughout the whole meeting of the Local Council, thus providing the possibility of commenting on the individual items on the agenda of the Local Council, such as the members of the municipality.

The city of Košice is divided into 22 city districts, which were the subjects of our research. Out of the 22 city districts surveyed, 16 city districts had their Rules of Procedure published on their website, 5 city districts did not publish their Rules of Procedure on the website, and 1 city district had no website.

According to Art. 26, par. 5 of the Constitution of the SR, public authorities are obliged to provide information on their activities in the state language and in appropriate manner. The legal lex specialis standard in this case is Act No. 211/2000 Coll. on Free Access to Information and on Amendments to Certain Acts (Freedom of Information Act). According to $\$ 5$ par. 2 of the above-mentioned Act, the municipality (city, city district) is obliged to 
publish information concerning the activities of the Municipal (local, city) Council. One such information is, in our view, the Rules of Procedure of the Local Council, which regulate the conditions and rules of the Municipal Council activities, and in particular in the process of negotiation, adoption of resolutions and general regulations. We base our opinion on the principle that the Law on Freedom of Information was reflected in the legislation and that what is not secret is public.

Regarding the availability of the Rules of Procedure of the Local Councils in the city districts of Košice, we consider that it is important to emphasize the fact, based from $\$ 6$ par. 1 , that city districts of Košice are obliged to have a website 5 . In connection with $\$ 4$ par. 1 and 2 of the Freedom of Information Act, obliged entities shall disclose information in a way that allows mass access to an unlimited circle of applicants, especially via the internet. In the case of Košice city districts, which are obliged to have a website, it is their responsibility to publish information in the usual way, which in this case also means publishing at the municipality's website.

When examining the Rules of Procedure, we focused on two facts. The first was the inclusion of a separate item on the agenda of the Local Council - The Public word - within which the inhabitants of the municipality can express their opinion (Table 1). The second fact to which we have focused our attention has been the Rules of Procedure regulation of the ability to give the floor to the inhabitant to the individual items on the agenda of the Local Council in the debate (Table 2). 
Table 1

\begin{tabular}{|c|c|}
\hline City district of Košice & $\begin{array}{l}\text { Separate item of discussion LC6: } \\
\text { "The Public Word" }\end{array}$ \\
\hline Košice - Barca & Separate item of LC discussion \\
\hline Košice - Dargovských hrdinov & Unedited \\
\hline Košice - Džungla & Web site does not exist \\
\hline Košice - Juh & Separate item of LC discussion \\
\hline Košice - Kavečany & Not published RP7 \\
\hline Košice - Košická Nová Ves & Unedited \\
\hline Košice - Krásna & Unedited \\
\hline Košice - Lorinčík & Unedited \\
\hline Košice - Luník IX & RP Not published \\
\hline Košice - Myslava & Unedited \\
\hline Košice - Nad jazerom & Unedited \\
\hline Košice - Pereš & Unedited \\
\hline Košice - Polov & Unedited \\
\hline Košice - Šaca & Unedited \\
\hline Košice - Šebastovce & RP Not published \\
\hline Košice - Sever & Unedited \\
\hline Košice - Sídlisko KVP & Unedited \\
\hline Košice - Sídlisko Ťahanovce & Unedited \\
\hline Košice - Staré Mesto & Unedited \\
\hline Košice - Ťahanovce & RP Not published \\
\hline Košice - Vyšné Opátske & RP Not published \\
\hline Košice - Západ & Separate item of LC discussion \\
\hline
\end{tabular}

Source: Custom research from data of the Rules of Procedure of the Košice city districts 


\section{Table 2}

\begin{tabular}{|c|c|}
\hline City district of Košice & $\begin{array}{l}\text { Opportunity of giving a speech to the inhabitants of the city } \\
\text { district within the individual items of the agenda of the Local } \\
\text { Council }\end{array}$ \\
\hline 1 & 2 \\
\hline Košice - Barca & $\begin{array}{c}\text { The resident may be given the floor. The Local Council decides } \\
\text { by voting. }\end{array}$ \\
\hline $\begin{array}{l}\text { Košice - Dargovských } \\
\text { hrdinov }\end{array}$ & $\begin{array}{l}\text { The resident of the municipality shall be given the floor only with } \\
\text { the consent of the members of the Local Council. }\end{array}$ \\
\hline Košice - Džungla & Web site does not exist \\
\hline Košice - Juh & $\begin{array}{l}\text { The resident of the municipality shall be given the floor } \\
\text { by voting of the members of the Local Council. }\end{array}$ \\
\hline Košice - Kavečany & RP Not published \\
\hline Košice - Košická Nová Ves & Unedited \\
\hline Košice - Krásna & $\begin{array}{l}\text { Members of the Local Council decide to give a word to } \\
\text { a resident by a simple majority vote. }\end{array}$ \\
\hline Košice - Lorinčík & $\begin{array}{l}\text { The resident can get a floor at the section "Other". The individual } \\
\text { will be given the floor on the individual items after the speeches } \\
\text { of the council members. }\end{array}$ \\
\hline Košice - Luník IX & RP Not published \\
\hline Košice - Myslava & $\begin{array}{l}\text { The resident of the municipality shall be given the floor by voting } \\
\text { of the members of the Local Council. }\end{array}$ \\
\hline Košice - Nad jazerom & Unedited \\
\hline Košice - Pereš & Unedited \\
\hline Košice - Polov & $\begin{array}{l}\text { The resident of the municipality shall be given the floor by voting of } \\
\text { the members of the Local Council. }\end{array}$ \\
\hline Košice - Šaca & $\begin{array}{l}\text { The chairman shall give the citizen the floor on the directly } \\
\text { discussed item on the agenda if an absolute majority of the Members } \\
\text { present, on a proposal from the Member, decides so. If a citizen } \\
\text { wants to get out of the program, the chairman will give him the floor } \\
\text { under "Other" section. }\end{array}$ \\
\hline Košice - Šebastovce & Not published RP \\
\hline Košice - Sever & $\begin{array}{l}\text { Members of the Local Council decide to give a word to a resident by } \\
\text { a simple majority vote. }\end{array}$ \\
\hline
\end{tabular}




\begin{tabular}{|c|c|}
\hline 1 & 2 \\
\hline Košice - Sídlisko KVP & $\begin{array}{r}\text { The chairman may give the floor to the citizen in the debate. The } \\
\text { Council decides on the assignment of the word by voting. }\end{array}$ \\
\hline $\begin{array}{c}\text { Košice - Sídlisko } \\
\text { Ťahanovce }\end{array}$ & $\begin{array}{r}\text { The resident of the municipality shall be given the floor by voting of } \\
\text { the members of the Local Council. }\end{array}$ \\
\hline $\begin{array}{c}\text { Košice - Staré Mesto } \\
\text { Košice - Ťahanovce }\end{array}$ & $\begin{array}{r}\text { The resident may be given the floor. The Local Council decides by } \\
\text { voting to whom will be the floor given. }\end{array}$ \\
\hline Košice - Vyšné Opátske & RP Not published \\
\hline Košice - Západ & RP Not published \\
\hline
\end{tabular}

Source: Custom research from data of the Rules of Procedure of the Košice city districts

At this point, it is important to state that all city districts that have published Rules of Procedure on their websites have a modified section of giving the word for a Member of the National Council of the Slovak Republic, a Member of the European Parliament, a representative of the Government of the Slovak Republic or a representative of another state organization, based from Municipalities Act.

The above-mentioned data from the Local Councils Rules of Procedure of the Košice city districts shows that Local Councils regulate the active participation of its inhabitants very briefly, in some places vaguely, or not at all. In the case of city districts, which adjust the granting of the word to the municipality's citizen in the debate on individual items of the Local Council, the giving of the word to the selected citizen is subject of voting by the members of the Local Council and the voting decides if the word will or will not be given. In the case of the inclusion of a separate item on the agenda of the Local Council - "The Public word", within which the inhabitants of the municipality can express their opinions, suggestions and comments, only three city districts had this section in their Rules of Procedure ${ }^{8}$. 


\section{Conclusion}

An important part of the democratic and legal nation is the territorial self-government, namely the Municipal self-government. Public power is manifested through the Municipal self-government, also named as decentralized public power, with the source of which is the inhabitants of the municipality (see more: Sitek, 2016, 236). There is a serious lack in current legislation, which could be considered as considerable disproportion, in the case of giving words to individual items on the agenda of a municipalities to a resident, a deputy of the National Council of the Slovak Republic, a deputy of the European Parliament, or a deputy of other state organ. In our opinion, the lawgiver should in the Act on Municipal Establishment, as in the case of the above-mentioned persons, regulate the participation of the inhabitants of the municipality in the meetings of the Municipal Council, or set the conditions under which the citizen of the municipality must be given the word, which the municipalities will have to obligatorily list in their Rules of Procedure. On the other hand, we do not support the idea that the word should be granted to a resident of a municipality at a Local Council meeting whenever he / she asks for it, as it could result in disrupting the peaceful and smooth conduct of the negotiations. However, an appropriate solution would to set a limited period of time in the debate on the individual items of the agenda, within which the inhabitants of the municipality may also be involved. This solution would be adequate because the inhabitants of the municipality are considered as a source of power and their decisions determine the elected bodies of the municipality.

\section{Bibliography}

Alman, T. (2018). Spoluúčast' obyvatelov obce a verejnosti na rozhodovaní obecného zastupitel'stva In: Verejná správa $\mathrm{v}$ súčasnom demokratickom a právnom štáte . Recenzovaný zborník príspevkov z medzinárodnej vedeckej konferencie, Čast' 1., Košice 2018. ŠafárikPress. ISBN 9788081527005.

Alman,T. (2017). Petičné právo a obecná samospráva. In: Verejná správa a spoločnost’ 2/2017. Košice: Fakulta verejnej správy UPJŠ v Košiciach. ISSN 1335-7182.

Giżyńska, M., Bułajewski, S. (2018). Referendum as a form of activity of civil society. Journal of Modern Science, 39(4), 119-133. https://doi.org/10.13166/ jms/103108. 
Jesenko, M. (2017). Právo obce na samosprávu a normotvorba obcí. Košice: Univerzita Pavla Jozefa Šafárika v Košiciach, Fakulta verejnej správy. ISBN 9788081525391.

Krunková, A. (2014). Priama demokracia ako suplementárny prostriedok v normotvorne obcí. In: Teória a prax komunálnej normotvorby. Recenzovaný zborník príspevkov $\mathrm{z}$ vedeckej konferencie s medzinárodnou účastou Košice, 23. -24. 10. 2014. Fakulta verejnej správy UPJŠ v Košiciach. ISBN 9788081522277.

Krunková, A. (2016). Samospráva a priama demokracia - teoretické východiská. In: Studialuridica Cassoviensia, ročník 4. 2016. ISSN 1339-3995.

Palúš, I. (2017). Teoreticko-právne východiská obecnej samosprávy (so zameraním na podmienky Slovenskej republiky). In: Formy uskutočňovania obecnej samosprávy. Zborník príspevkov z medzinárodnej vedeckej konferencie. Košice: UPJŠ, Fakulta verejnej správy. ISBN 9788081525421.

Palúš, I. a kol., (2018). Formy uskutočňovania obecnej samosprávy. Košice: UPJŠ, Fakulta verejnej správy. ISBN 9788081526633.

Palúš, I., Jesenko, M., Krunková, A. (2010). Obec ako základ územnej samosprávy. Košice: Univerzita P. J. Šafárika v Košiciach, Fakulta verejnej správy. ISBN 9788081290039.

Pavlíček, V. a kol. (2014). Ústavní právo a státověda. 1. díl, Obecná státověda.Praha: Leges. ISBN 9788075020536.

Rokovacie poriadky mestských častí mesta Košice.

Sitek, B. W. (2018). Autonomy of local communities from the perspective of Roman law and modern normative solutions. Journal of Modern Science, 36(1), 127-143. https://doi.org/10.13166/jms/86366.

Sitek M. (2016) Prawa (potrzeby) człowieka w ponowoczesności, Warszawa: C.H.Beck. ISBN 9788325589226.

Sotolář, J. (2011). Samospráva obce. Obecné zriadenie na Slovensku. Košice: SOTAC, s. r. o. ISBN 9788089446230.

Tekeli, J. (2016). Kompetenčné právo v obecnej samospráve. Konfliktné oblasti. Bratislava: WoltersKluwer, s. r. o. ISBN 9788081683367.

Zákon č. 211/2000 Z. z. o slobodnom prístupe k informáciám a o zmene a doplnení niektorých zákonov (zákon o slobode informácii).

Zákon č. 369/1990 Zb. o obecnom zriadení v znení neskorších predpisov.

Zákon č. 460/1992 Zb. Ústava Slovenskej republiky. 


\section{Endnotes}

1 This contribution was processed within the framework of the project VEGA 1/0367/19 „Kompetencie obecnej samosprávy a podiel štátu na ich uskutočňovani” (see more: Giżyńska, Bułajewski, 2018, 119-133)

${ }^{2}$ In a broader sense, petitions, complaints, suggestions, in the narrower sense referendum and gathering of inhabitants of the municipality are considered to be direct democracy.

${ }^{3}$ The municipal council declares the meeting to be non-public if the subject of the meeting is information protected according to eg Sections 17 to 20 of Act no. 513/1991 Coll. Commercial Code, $\$ 91$ of Act no. 483/2001 Coll. on Banks and on Amendments to Certain Acts, Section 11 of Act No. 563/2009 Coll. on Tax Administration (Tax Code) and on amendments to certain acts, as amended, Act no. 122/2013 Coll. on the protection of personal data and on amendments to certain acts, as amended by Act No. 84/2014 Coll

${ }^{4}$ Expressing their opinion at the meetings of the Municipal Council to the residents of the municipality, means the right of the inhabitant to appear and present their opinions, suggestions, comments, complaints or suggestions concerning any activity within and outside the municipality.

${ }^{5}$ The information referred to in Article 5 shall be made public in a manner allowing collective access. This obligation does not apply to individual and to municipalities that are not cities.

${ }^{6}$ Local Council

${ }^{7}$ Rules of Procedure

${ }^{8}$ Some authors, such as Alman (2018), develop the idea of Municipal Councils commissions or Municipal Councils, where similarly, valid legislation does not respond to the issues of the (un)public of their meetings or the institute of giving speech to the involved inhabitants of the municipality 